\title{
Active balancing circuit for advanced lithium-ion batteries used in photovoltaic application
}

\author{
J.F. Reynaud ${ }^{1,2}$, C. E. Carrejo ${ }^{1}$, O. Gantet ${ }^{1}$, P. Aloïsi ${ }^{1}$, B. Estibals ${ }^{1,2}$, C. Alonso ${ }^{1,2}$ \\ ${ }^{1}$ CNRS ; LAAS ; 7 avenue du colonel Roche, F-31077 Toulouse, France \\ Phone number: +0033561336391 \\ E-mail: jfreynau@laas.fr, cecarrej@laas.fr, ogantet@laas.fr, paloisi@laas.fr, bestibal@laas.fr, alonsoc@laas.fr \\ ${ }^{2}$ Université de Toulouse ; UPS, INSA, INP, ISAE ; LAAS ; F-31077 Toulouse, France
}

\begin{abstract}
An approach to the analysis and design of a bidirectional DC power converter for the cell voltage balancing control of a series connected lithium-ion battery string is presented in this paper. The proposed Cell Balancing Circuit $(\mathrm{CBC})$ is designed to transfer the energy from the fully charged battery cell to the weakest one using a switch mode power converter operation. This operation maintains cell batteries at the same State-Of-Charge (SOC) and voltage range. Unlike previous battery balancing circuits, the balancing method uses only one magnetic component, resulting small size system. Simulation and experimental results show that the proposed cell balancing method can not only enhance the bidirectional battery equalization performance, but can also reduce the switching loss during the equalization period. Experiment results are provided to verify the operating principle of the proposed balancing method. Specific conditions of experiments are used to reproduce photovoltaic operations.
\end{abstract}

\section{Key words}

Active balancing, Lithium-ion battery, Bidirectional micro converter, Photovoltaic.

\section{Introduction}

Because a single battery cell presents low nominal voltage (limited due to the active materials chemistry), battery cells are usually connected in series to be employed in many applications, such as electric vehicles (EV), hybrid electric vehicles (HEV), photovoltaic (PV) systems or telecommunication battery energy systems. Unbalanced cell voltage within a series string can be attributed to the differences in the cell's internal resistance, unbalanced State-Of-Charge (SOC) between cells, degradation and the ambient temperature gradients during charging and discharging [1]-[2]. Voltage monitoring and current diversion equalization circuits and Battery Management Systems (BMS) have been developed to prevent unbalances during charging and discharging in a series connected battery cells [3]. This repeated charge and discharge phenomenon causes a cell mismatch problem because lithium-ion batteries have inevitable differences in chemical and electrical characteristics from manufacturing, and accelerate asymmetrical cell degradation with aging [4]. The problem is that when these imbalanced batteries are left in use without any control, such as cell balancing, the energy storage capacity decreases severely, and in the worst case, there may be an explosion or fire. Lithium-ion batteries require careful management, particularly with regard to overcharge and undercharge problems. Thus, charge equalization for a series connected battery string is necessary to prevent these phenomena and extend the useful lifetime. Numerous charge balancing circuits have been presented and well summarized in [5]. They can be classified into two categories, dissipative and nondissipative. Example of dissipative balancing method could be based on shunt resistive method. It is the simplest and cheapest cell balancing. This method could be operated continuously on each cell independently but this method presents high energy losses, which reduces the energy efficiency. Example of a non-dissipative method could be based on multiple winding transformers with advantage of being an effective low-cost equalization, but it is difficult to implement multiple windings in a single transformer [6]. In a dedicated DC converter approach, a very low voltage stress can be achieved because the use of a bidirectional DC converter, but there is a high complexity of controlling the bidirectional DC power converter [7]. Another non dissipative method could be based on a switched capacitor applied to every two adjacent cells [8]. This method can balance cells in a short time, but it requires a large number of switches, so lots of energy is dissipated in the switches and capacitor. The main contribution of 
this paper is the use of an active cell balancing method in the design and analysis of the individual cell balancing control of the lithium-ion battery strings used in photovoltaic applications. A specific charge controller has been inserted in the conversion chain to optimize the charge of the battery pack and presented in section II. In section III, a brief description of a shunt balancing method based on dissipative resistance is exposed. In section IV, the principle of the active cell balancing method is presented using micro converters buck-boost. Two designed cases are used to demonstrate the performance in the proposed active balancing method for reducing losses and increasing the equalization efficiency and battery string capacity. Both balancing method will be compared applying PV production profiles. Analysis of losses is also included to evaluate performances of each method. In section IV, two practical designs example and experimental results are presented to compare both balancing methods in specific operation conditions.

\section{System configuration}

\section{A. Architecture Specifications}

To improve the photovoltaic conversion chain, it is usually used DC power converters associated with a MPPT control optimizing the research of the Maximum Power Point (MPP) delivered by the PV generator. Coupling with a controlled storage system, the PV conversion chain will be obviously more efficient. Figure 1 describes the functional architecture of the power architecture module with all subsystems included.

The architecture of the system studied includes a PV generator, a storage system and an optimal conversion chain including MPPT and electronic management system with different electrical functions to be connected to a load with a maximum security. The principal function of this architecture is to transfer the Maximum Power from a PV panel and store and/or restitute the energy to the load. For that, an electronic management system was designed and implemented on a microcontroller to control all subsystems [9]. The DC power converter connected to the PV generator is associated with a Maximum Power Point Tracking (MPPT) optimizing the research of the Maximum Power delivered by the PV generator. The nonreversibility of this static converter will protect the panel from a possible battery discharge of electrical current. Electronic management system and energy transfer regulator will ensure the management of the battery, protection and control system included in the power converter.

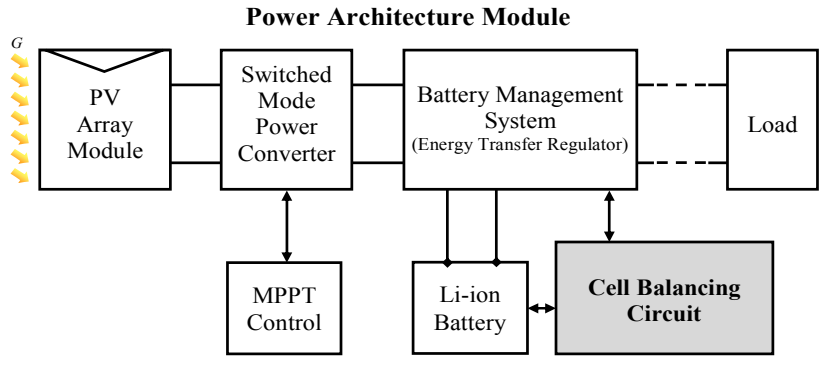

Fig. 1. Functional power architecture module.
Control algorithms would be adapted to the lithiumion electrochemistry used (i.e. lithium nickel oxide). The developed operating system takes into consideration several characteristics of the individual battery cells and manages, depending on the load profile, the energy flow which has to be controlled.

\section{B. Example of Lithium-ion battery Specifications}

Actual active materials for lithium-ion batteries present excellent properties of cyclability and lifetime. Research has been based on the storage system adaptation to improve efficiency. A conventional couple of electrodes, natural graphite $\left(\mathrm{LiC}_{6}\right)$ for the negative electrode and lithium nickel oxide $\left(\mathrm{Li}(\mathrm{Ni}, \mathrm{Co}, \mathrm{Al}) \mathrm{O}_{2}\right)$ for the positive electrode, has been studied and integrated to the power module. This electrochemical system has demonstrated in cylindrical design cell its high cyclability (over 4000 cycles at $80 \%$ Depth-OfDischarge) and its long lifetime (8 years without demonstrating that the system has been aged significantly) [10]. The batteries used in this power module consist of stacks of 3.6V, 10 Amps Hour (Ah) Liion cells. The battery pack contains six cells in series, a nominal voltage of $21.6 \mathrm{~V}$. Curves of constant current charge and discharge at $25^{\circ} \mathrm{C}$ are represented in Figure 2.

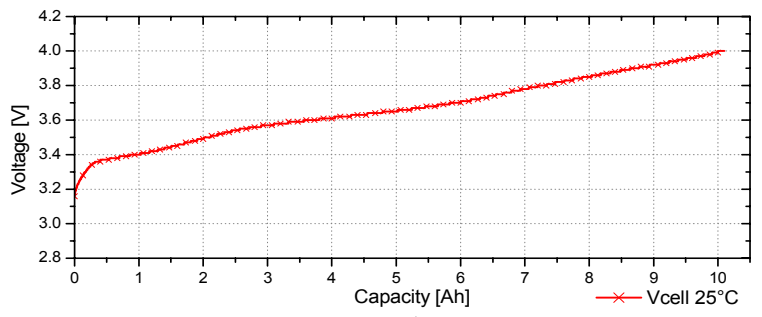

a)

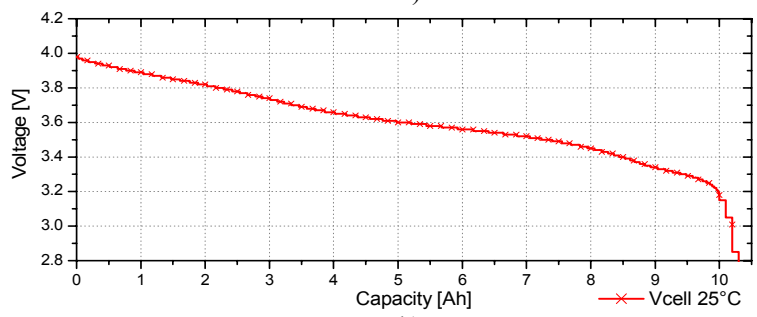

b)

Fig. 2. Battery cell charging (a) and discharging (b) voltage curves at constant current $\mathrm{C} / 10,25^{\circ} \mathrm{C}$.

Observing the slope of the charge and discharge curves for this kind of lithium-ion technology, we can easily estimate the State-Of-Charge of battery cells.

\section{Context of the study}

Researches of new topologies of power converters for battery management have been done in the Laboratory for Analysis and Architecture of Systems (LAAS) and specifically for renewable energy applications. Two cell balancing method have been elaborated to compare performances in different working conditions. The first solution developed is a classical structure, the shunt balancing method, which will be our reference. The second solution is based on micro converters and tries to improve efficiency with same performances. 


\section{Topology description of the shunt balancing method}

The shunt balancing method consists in discharging cells whose voltages are superior to $20 \mathrm{mV}$ at the cell with the value of the lowest voltage through a resistor network of dissipation $\left(R_{E Q n}\right)$ and MOSFET $\left(M_{E Q n}\right)$. It's an active balancing in terms of control via a microcontroller and thermal dissipative (Joule effect). The speed of the balancing will be proportional to the current through the balancing resistances. Figure 3 represents the electrical design of the shunt balancing method to $\mathrm{n}$ elements connected in series. Balancing voltage between cells is done through an algorithm introduced in a microcontroller. This algorithm compares voltages of each cell battery and activates MOSFET switches, if necessary. During charging or discharging the battery pack, balancing is done by diverting a portion of the current in the resistor $R_{\mathrm{EQ}}$. Discharging cells with the highest potential difference contributes to the balancing operation and bring all cell voltages at equilibrium.

Estimated losses for this shunt balancing method can be evaluated by the following equation:

$$
\mathrm{n}\left(\mathrm{R}_{\mathrm{dson}} * \mathrm{I}_{\mathrm{EQ}}^{2}(\mathrm{t})\right)+\mathrm{R}_{\mathrm{EQ}} * \mathrm{I}_{\mathrm{EQ}}^{2}(\mathrm{t})
$$

With $n$ the number of battery cells, $I_{E Q}$ (A) the balancing current and $R_{E Q}(\Omega)$ the dissipative resistance.

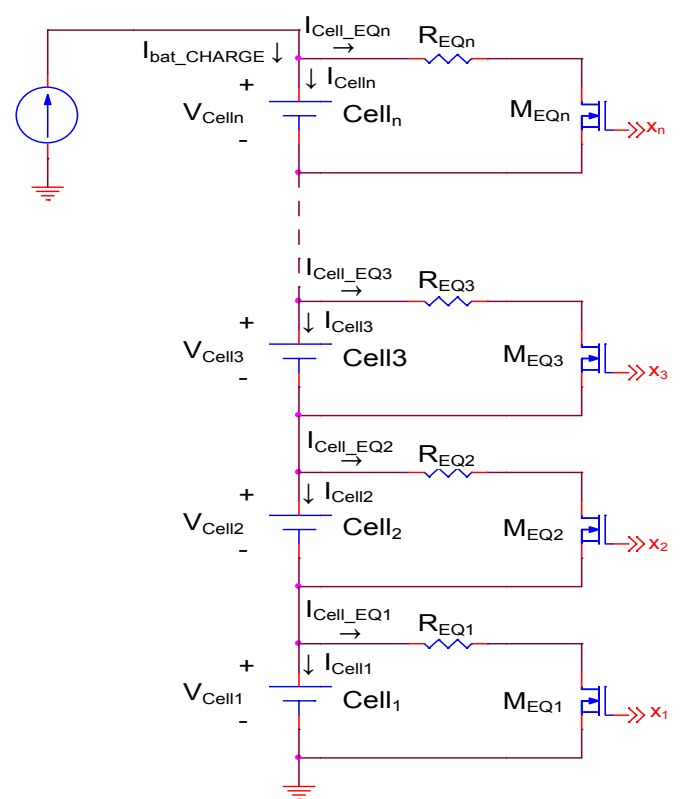

Fig. 3. Principle circuit of the shunt cell balancing method for $n$ cell in series.

The values of the balancing current and balance sheet losses for this method are given in section IV for several experiments determining the average running time of the active cell constituting the balancing network. The experimental results corresponding to the development of this method are analyzed and the successive improvements as innovative solutions balancing tend to increase the speed balancing. Figure 4 shows the experimental prototype used to demonstrate the performance of the proposed shunt balancing method in PV application.

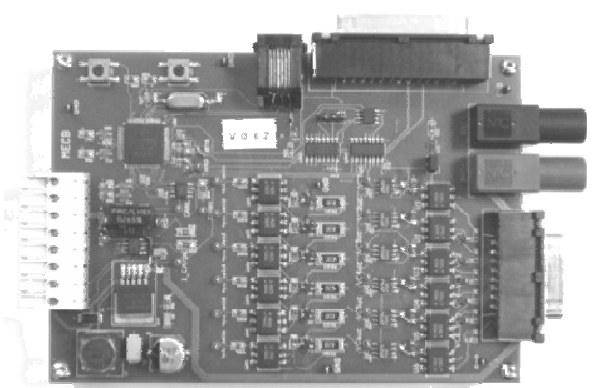

Fig. 4. Shunt cell balancing method prototype implemented for 6 cells in series.

\section{Topology description of the active cell balancing method}

A Cell Balancing Circuit (CBC) for battery pack applications has been proposed to equalize battery strings. The bidirectional buck-boost battery equalization circuit has many advantages such as a higher equalization efficiency for non dissipative current diverts, and a modular design approach. The disadvantage of this equalization circuit is that the stored energy in the inductor is transferred to the weakest cell only in the second part of the switching period $\left(\mathrm{T}_{\mathrm{OFF}}\right)$. Battery equalization control should be implemented to restrict the charge and discharge current to the allowable cell limitations in the battery string. Cell balancing control is designed to obtain the maximum capacity from the battery string. However, battery string charging and discharging are limited by any single cell reaching its end-of-charge voltage and by low voltage threshold, respectively. Cell balancing algorithms search to efficiently remove energy from a stronger cell and transfer that energy into a weaker one until the cell voltage is equalized across all cells. Complete cell voltage balancing is performed using a bidirectional DC power converter based on the buck-boost converter. Active balancing methods are intended to optimize the charging of the battery pack to make it uniform for all cells and thus avoid any voltage disparity that could affect the life time of the battery pack [11].

The objective of this method is to use a set of active components assembled on a bidirectional converter operating as micro converters buck-boost for voltage balancing between cells as shown in Figure 5. The control algorithm associated has to manage state of all MOSFETs included in the conversion system. For that, the algorithm receives information from the BMS and compares cells voltage to active cell balancing. The target of this process is the pack battery charge optimization in order to get the same charge for each cell and so to get the optimum battery life time in PV applications. The well known method is to discharge the highest charged element through resistances. It is an easy system but dissipative. The proposed solution is to use a buck-boost converter to transfer the energy from the highest charged battery to the lowest one and so on. The developed algorithms will connect the highest cell in the string to the converter input and the output to the lowest one. Battery cells are classified by their voltage and stateof-charge by a microcontroller $(\mu \mathrm{C})$. 


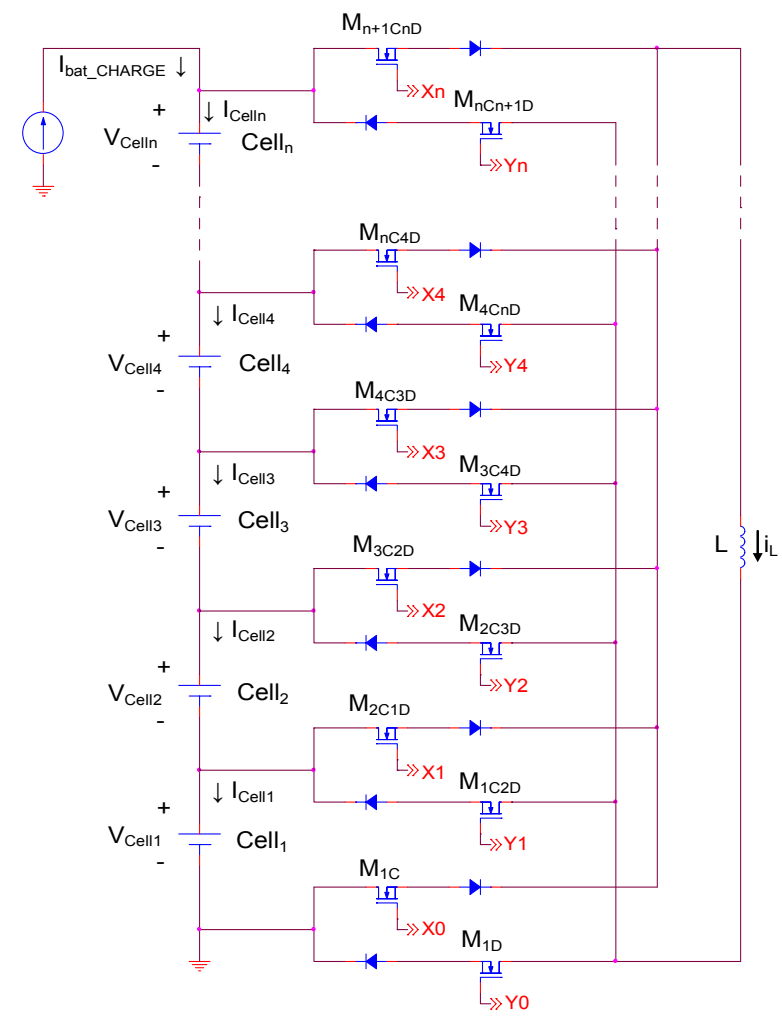

Fig. 5. Principle circuit of cell balancing method using buckboost micro converter for $\mathrm{n}$ cell in series.

Micro converters will be controlled in voltage according to the system, protections and the battery cells. A SPI bus is used for the all dialogues between $\mu \mathrm{C}$ and measurement devices. MOSFETs are most of the time high side driven.

For example with two adjacent cells, if the cell noted $\mathrm{Cell}_{4}$ is fully charged and the $\mathrm{Cell}_{3}$ is the lowest charged when charging process, the current flows through the micro converter following the path as shown in Figure 6.

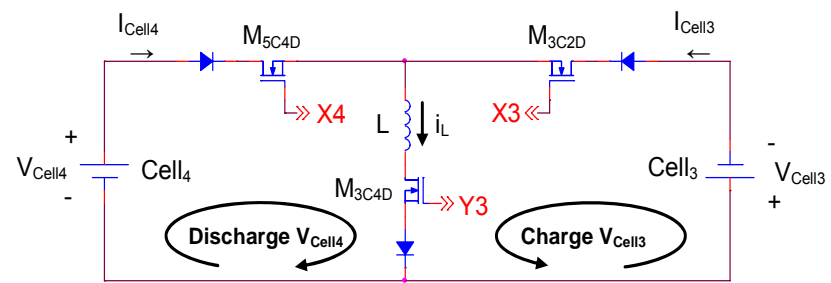

Fig. 6. Equivalent circuit of the buck-boost converter when energy transfers between $\mathrm{Cell}_{4}$ and $\mathrm{Cell}_{3}$.

During $\mathrm{T}_{\mathrm{ON}}=\alpha \mathrm{T}_{\mathrm{c}}\left(\mathrm{M}_{\mathrm{nC} 4 \mathrm{D}}\right.$ and $\left.\mathrm{M}_{3 \mathrm{C} 4 \mathrm{D}}=>\mathrm{ON}\right)$ the quantity of charge which is transferred from battery $\mathrm{Cell}_{4}$ to the inductor $\mathrm{L}$ is:

$$
\mathrm{Q}_{\mathrm{Cel14}}=\frac{1}{2} \mathrm{i}_{\mathrm{Lmax}_{\max }} \alpha \mathrm{T}_{\mathrm{c}}=\frac{1}{2} \frac{\mathrm{V}_{\text {cell4 }}}{\mathrm{L}}\left(\alpha \mathrm{T}_{\mathrm{c}}\right)^{2}
$$

During $\mathrm{T}_{\mathrm{OFF}}=(1-\alpha) \mathrm{T}_{\mathrm{c}}\left(\mathrm{M}_{3 \mathrm{C} 2 \mathrm{D}}\right.$ and $\left.\mathrm{M}_{3 \mathrm{C} 4 \mathrm{D}}=>\mathrm{ON}\right)$ the quantity of charge which is transferred from inductor to battery $\mathrm{Cell}_{3}$ is:

$$
\mathrm{Q}_{\mathrm{Cel1}}=\mathrm{Q}_{\mathrm{Cel1}}=\frac{1}{2} \frac{\mathrm{V}_{\text {cell }}}{\mathrm{L}}\left(\alpha \mathrm{T}_{\mathrm{c}}\right)^{2}
$$

In the same way, the current passes of charging battery and discharging battery can be selected by controlling the gate signal of switches (MOSFETs). When two or more battery cells are fully charged, those battery cells have to be discharged turn and turn about to avoid overcharging.

Table I shows an example, for 4 cells in series, different possible switching (actions on $\mathrm{Xn}$ and $\mathrm{Yn}$ ) and the inputs of decoder controlled by the microcontroller.

Table I. Switching actions on Xn and Yn

\begin{tabular}{c|c|c|c|c|c|c} 
& Cell $_{1}>\mathrm{Cell}_{2}$ & Cell $_{1}>\mathrm{Cell}_{3}$ & Cell $_{1}>\mathrm{Cell}_{4}$ & Cell $_{2}>\mathrm{Cell}_{1}$ & Cell $_{2}>\mathrm{Cell}_{3}$ & Cell $_{2}>\mathrm{Cell}_{4}$ \\
\hline \hline $\mathrm{T}_{\mathrm{ON}}=\alpha \mathrm{T}_{\mathrm{c}}$ & $\mathrm{X}_{1}-\mathrm{Y}_{0}$ & $\mathrm{X}_{1}-\mathrm{Y}_{0}$ & $\mathrm{X}_{1}-\mathrm{Y}_{0}$ & $\mathrm{X}_{2}-\mathrm{Y}_{1}$ & $\mathrm{X}_{2}-\mathrm{Y}_{1}$ & $\mathrm{X}_{2}-\mathrm{Y}_{1}$ \\
$\mathrm{~T}_{\mathrm{OFF}}=\mathrm{T}_{\mathrm{c}}-\mathrm{T}_{\mathrm{ON}}$ & $\mathrm{X}_{1}-\mathrm{Y}_{2}$ & $\mathrm{X}_{2}-\mathrm{Y}_{3}$ & $\mathrm{X}_{3}-\mathrm{Y}_{4}$ & $\mathrm{X}_{0}-\mathrm{Y}_{1}$ & $\mathrm{X}_{2}-\mathrm{Y}_{3}$ & $\mathrm{X}_{3}-\mathrm{Y}_{4}$
\end{tabular}

\begin{tabular}{c|c|c|c|c|c|c} 
& Cell $_{3}>\mathrm{Cell}_{1}$ & Cell $_{3}>\mathrm{Cell}_{2}$ & Cell $_{3}>\mathrm{Cell}_{4}$ & Cell $_{4}>\mathrm{Cell}_{1}$ & Cell $_{4}>\mathrm{Cell}_{2}$ & Cell $_{4}>\mathrm{Cell}_{3}$ \\
\hline \hline $\mathrm{T}_{\mathrm{ON}}=\alpha \mathrm{T}_{\mathrm{c}}$ & $\mathrm{X}_{3}-\mathrm{Y}_{2}$ & $\mathrm{X}_{3}-\mathrm{Y}_{2}$ & $\mathrm{X}_{3}-\mathrm{Y}_{2}$ & $\mathrm{X}_{4}-\mathrm{Y}_{3}$ & $\mathrm{X}_{4}-\mathrm{Y}_{3}$ & $\mathrm{X}_{4}-\mathrm{Y}_{3}$ \\
$\mathrm{~T}_{\mathrm{OFF}}=\mathrm{T}_{\mathrm{c}}-\mathrm{T}_{\mathrm{ON}}$ & $\mathrm{X}_{0}-\mathrm{Y}_{1}$ & $\mathrm{X}_{1}-\mathrm{Y}_{2}$ & $\mathrm{X}_{3}-\mathrm{Y}_{4}$ & $\mathrm{X}_{0}-\mathrm{Y}_{1}$ & $\mathrm{X}_{1}-\mathrm{Y}_{2}$ & $\mathrm{X}_{2}-\mathrm{Y}_{3}$
\end{tabular}

The control of micro converters is realized by a conventional voltage regulation. The operating time of the converter are adjusted for balancing needs to maintain permanently a maximum deviation of $20 \mathrm{mV}$ between each cell. Using this method and following figure 5, we can generalized to any cells of the battery pack through the command of MOSFETs (figure 7).

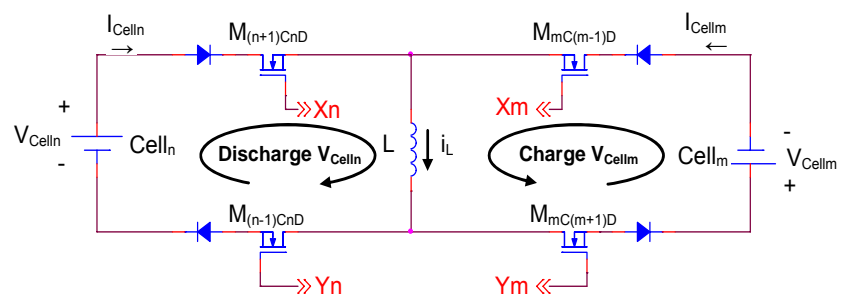

Fig. 7. Equivalent circuit of the buck-boost converter when energy transfers between $\mathrm{Cell}_{4}$ and $\mathrm{Cell}_{3}$.

Estimated losses for this active cell balancing method can be evaluated by the following equation:

$2 \mathrm{~N}\left(2 \mathrm{R}_{\mathrm{dson}} * \mathrm{i}_{\text {Lrms }}^{2}(\mathrm{t})\right)+2 \mathrm{~N}\left(2 \mathrm{~V}_{\mathrm{f}} * \mathrm{i}_{\text {Lavg }}(\mathrm{t})\right)+\mathrm{r}_{\mathrm{i}} * \mathrm{i}_{\text {Lrms }}^{2}(\mathrm{t})(4)$

With $N$ the number of micro converters involved in the balancing action where two cells are included at every stage of balancing ; $R_{\text {dson }}(\Omega)$, the conduction resistance of the MOSFET; $V_{f}(\mathrm{~V})$, the diode threshold voltage, and $r_{i}(\Omega)$, the winding resistance of the inductor $L$.

To obtain efficient results it is necessary to use voltage sensors with high accuracy allowing optimal control of balancing actions. A LTC6802 is used to have a maximum of voltage accuracy. A specific high bootstrapped side control has been implemented to control MOSFETs. Figure 8 shows the experimental prototype used to demonstrate the performance of the proposed active balancing method in PV application. 


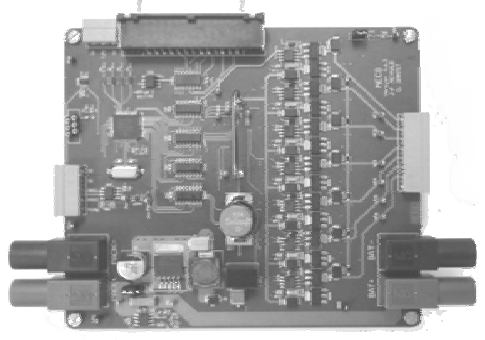

Fig. 8. Active cell balancing method prototype implemented for 6 cells in series.

\section{Experimental results}

To validate proposed equalization circuits, the two proposed balancing method was installed in a six cell battery strings for experiment to verify the performance of the proposed balancing methods. The driving signals for the two equalization circuits were controlled using a microcontroller based intelligent BMS system according to the sensed cell voltages. The driving signals were constructed using a logical switching algorithm following the flowchart and the intelligent decision strategy of the driving signal generating from the BMS and instructed by a PIC18F6585 microcontroller.

The experiment consists to apply two different PV profiles to charge the battery pack integrated at the power module. Battery charging will be optimal and use a DC power converter associated with a Maximum Power Point Tracking (MPPT) optimizing the research of the maximum power delivered by the PV generator. To perform results and to compare both balancing method a solar array simulator (Agilent E4360A) has been used. Figure 9 a) shows a sunny profile with a maximum power, after two hours working, at $30 \mathrm{~W}$ and figure $9 \mathrm{~b}$ ) shows a cloudy profile representative of PV power variations. All profiles applied to the system for experiment have a total duration of four hours.

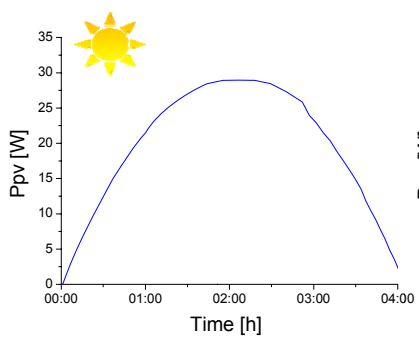

a)

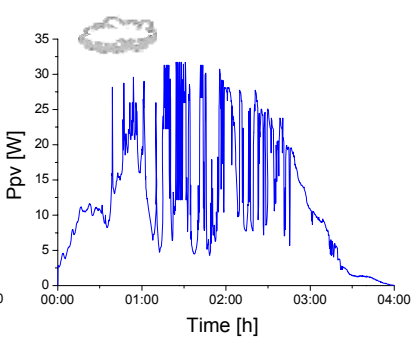

b)
Fig. 9. Photovoltaic profiles a) Sunny day, b) Cloudy day.

Figures 10, 11, 13 and 14 show experiments of the power module applying PV profiles described above. Results show that using active balancing circuit the maximum difference voltage, noted $\Delta V C$ Cell $l_{\max }$, between each cell follow specifications defined at $20 \mathrm{mV}$ during the full time experiment. Also, system data acquisition performs results that the quantity of charge store into the battery is sensibly the same for both experiments. Figure 12 and 15 resume values of $\Delta V C e{ }^{2} l_{\max }$ and compare results without balancing action. Conversion efficiency during battery charging with active balancing method is around $91.5 \%$ applying a sunny profile and $87.3 \%$ applying cloudy profile.
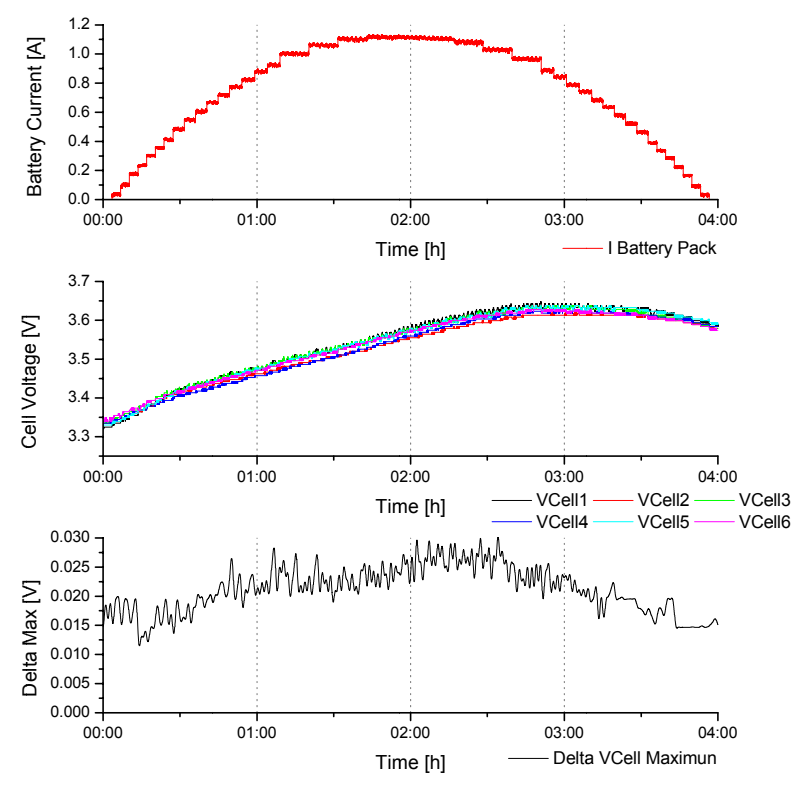

Fig. 10. Experiment of the charge of six lithium-ion cell in series with the shunt balancing method. Test conditions: Sunny $P V$ profile at $25^{\circ} \mathrm{C}$.
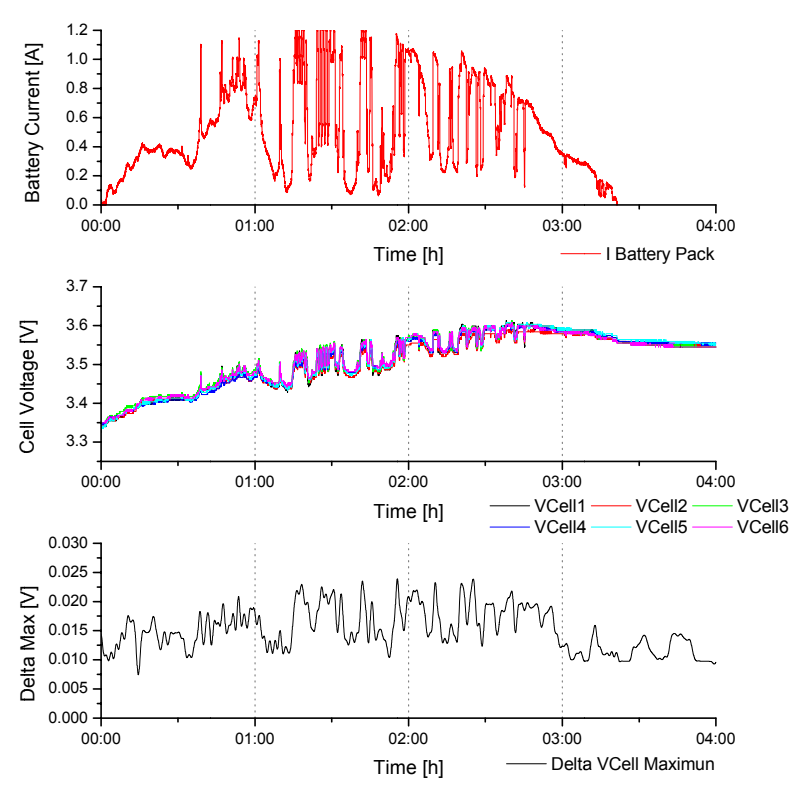

Fig. 11. Experiment of the charge of six lithium-ion cell in series with the shunt balancing method.

Test conditions: Cloudy PV profile at $25^{\circ} \mathrm{C}$.

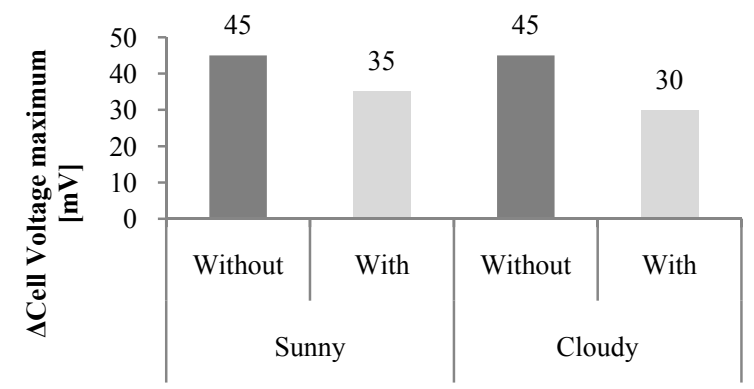

Fig. 12. Final results of $\Delta \mathrm{VCell}_{\max }$ applying or not shunt cell balancing for different PV Profiles. 

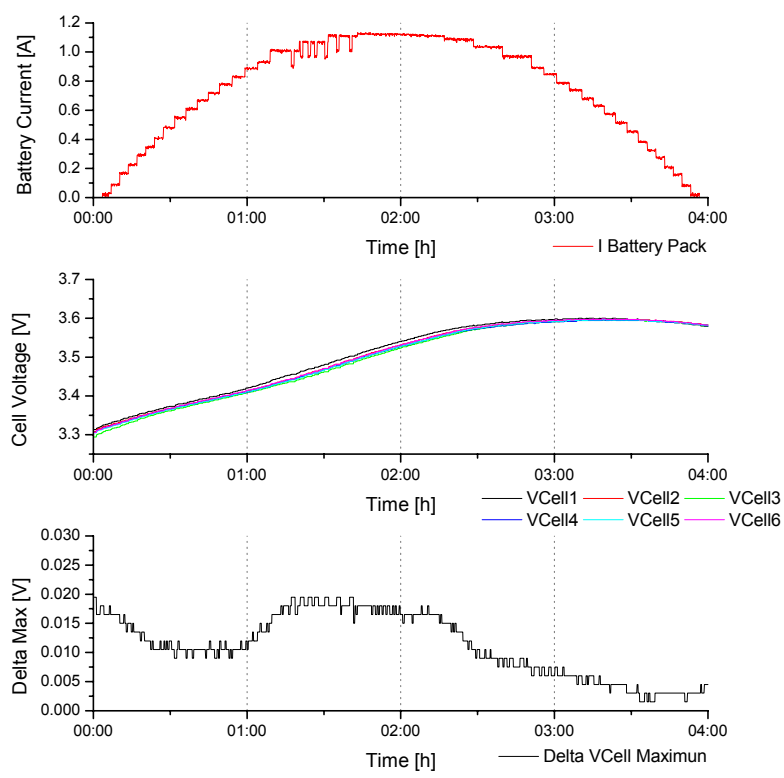

Fig. 13. Experiment of the charge of six lithium-ion cell in series with the active balancing method.

Test conditions: Sunny PV profile at $25^{\circ} \mathrm{C}$.
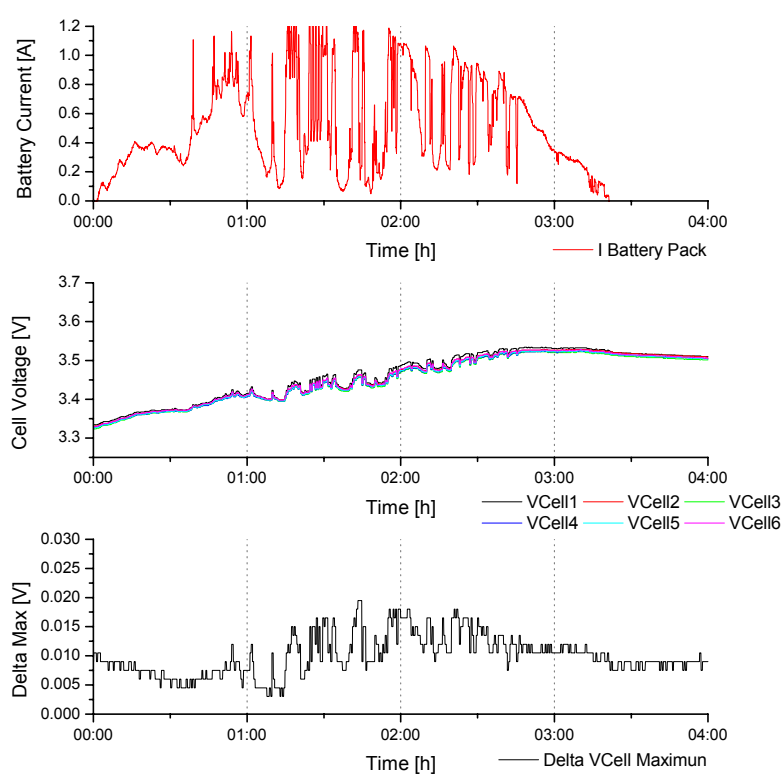

Fig. 14. Experiment of the charge of six lithium-ion cell in series with the active balancing method.

Test conditions: Cloudy PV profile at $25^{\circ} \mathrm{C}$.

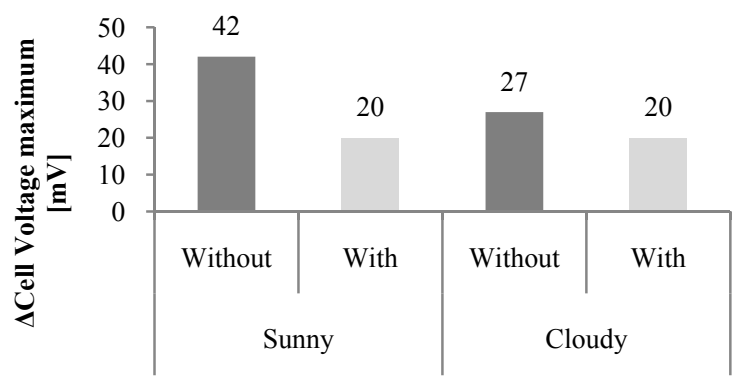

Fig. 15. Final results of $\Delta \mathrm{VCell}_{\max }$ applying or not active cell balancing for different PV Profiles.

\section{Conclusion}

An intelligent cell balancing circuit was proposed for bidirectional battery equalization of a series connected lithium-ion battery string. A buck-boost converter was employed to improve the dynamic equalization performance, and to guarantee that each cell voltage of the lithium-ion battery string would be operated within the safety region during the cell balancing period. The advantages of the proposed intelligent battery equalization circuit are summarized as follows.

- The proposed buck-boost converter topology accelerates the equalizing process. The equalization time is abbreviated and continuous compared with the conventional shunt balancing method under the same equalization conditions.

- The bidirectional cell balancing control circuit can be used in the charging or discharging state to extend lifetime of lithium-ion battery cells used in photovoltaic applications.

In system design of a practical lithium-ion based battery pack, the scope of cell imbalancing effects in the battery string applications must be evaluated comparing various solutions for cell balancing and execution time it requires in the charge process.

\section{References}

[1] S. Franger, F. Le Cras, C. Bourbon and H. Rouault, "Comparison between different $\mathrm{LiFePO}_{4}$ synthesis routes and their influence on its physico-chemical properties", Journal of Power Sources, 119 (2003) 252-257.

[2] S. S. Zangh, "The effect of the charging protocol on the cycle life of a Li-ion battery", Journal of Power Source, Vol. 161, pp. 1385, 2006.

[3] H.-S. Park, C.-E. Kim, C.-H. Kim, G.-W. Moon, J-H Lee, "Modularized Charge Equalizer for an HEV Lithium-Ion Battery String", IEEE Transaction on Industrial Electronics, vol. 56, no. 5, pp. 1464-1476, 2009.

[4] B. T. Kuhn, G. E. Pitel, and P. T. Krein, "Electrical properties and equalization of lithium-ion cells in automotive applications," IEEE Vehicle Power Propulsion, pp. 55-59, 2005.

[5] A. Baughman, M. Ferdowsi "Battery charge equalizationstate of the art and future trends," Future Transportation Technology conference, pp. 905-910, 2005.

[6] N. H. Kutkut, "Non-dissipative current diverter using a centralized multiwinding transformer," IEEE Power Electronics Specialists, pp. 648-654, 1997.

[7] Y.-S. Lee and G.-T. Cheng, "Quasi-resonant zero-currentswitching bidirectional converter for battery equalization applications," IEEE Transaction on Power Electronics, vol. 21, no. 5, pp. 1213-1224, 2006.

[8] A. C. Baughman and M. Ferdowsi, "Double-tiered switched capacitor battery charge equalization technique," IEEE Transaction on Industrial Electronics, vol. 55, no. 6, pp. 2277-2285, 2008.

[9] J.F. Reynaud, O. Gantet, P. Aloïsi, B. Estibals, C. Alonso, "New Adaptive Supervision Unit to Manage Photovoltaic Batteries", IEEE Industrial Electronics Society (IECON), Porto, 2009.

[10] Datasheet VL10E lithium-ion battery, SAFT documents, 2008, http://www.saftbatteries.com.

[11] Y.-S. Lee, M.-W. Cheng, "Intelligent Control Battery Equalization for Series Connected Lithium-Ion Battery Strings", IEEE Transaction on Industrial Electronics, vol. 52, no. 5, pp. 1297-1307, 2005. 